Article

\title{
Differentiation of Surface Water and Groundwater in a Karst System Using Anthropogenic Signatures
}

\author{
Benjamin Maas ${ }^{1}$, Eric W. Peterson ${ }^{2, *} \mathbb{D}$, Joe Honings ${ }^{3}$, Andrew Oberhelman ${ }^{2}$, Prince Oware ${ }^{2}$, \\ Ian Rusthoven ${ }^{2}$ and Andrew Watson ${ }^{2}$ \\ 1 Department of Environmental Science, Buena Vista University, 610 W 4th ST, Storm Lake, IA 50588, USA; \\ maas2@bvu.edu \\ 2 Department of Geography, Geology, and The Environment, Illinois State University, Campus Box 4400, \\ Normal, IL 61704, USA; ahoberh@ilstu.edu (A.O.); pkoware@ilstu.edu (P.O.); irrusth@ilstu.edu (I.R.); \\ alwats1@ilstu.edu (A.W.) \\ 3 Department of Geology \& Geophysics, Louisiana State University, E235 Howe-Russell-Kniffen, Baton Rouge, \\ LA 70803, USA; jhonin1@1su.edu \\ * Correspondence: ewpeter@ilstu.edu; Tel.: +1-309-438-7865
}

Received: 24 January 2019; Accepted: 26 March 2019; Published: 29 March 2019

\begin{abstract}
Surface water-groundwater interaction within a karstic system enhances contaminant transport, making karst aquifers susceptible to anthropogenic practices. Contaminated waters related to agricultural and animal husbandry in northwestern Illinois (USA) prompted this investigation. Six streams and five springs were sampled for 16 parameters to assess anthropogenic influences. Statistical analyses revealed differences in 13 of 16 parameters between the stream and spring waters. Rock-water interaction was identified as the dominant mechanism defining the chemistry for both waters, which were classified as $\mathrm{Ca}-\mathrm{Mg} \mathrm{HCO}_{3}$. Elevated nitrate as nitrogen $\left(\mathrm{NO}_{3}-\mathrm{N}\right)$, chloride $\left(\mathrm{Cl}^{-}\right)$, sodium, and potassium concentrations indicate that human activities have influenced the quality of both water types. All streams and springs had $\mathrm{NO}_{3}-\mathrm{N}$ concentration exceeding background levels, with concentrations ranging from 2.9 to $14.5 \mathrm{mg} / \mathrm{L}$ and 2.9 to $30.1 \mathrm{mg} / \mathrm{L}$, respectively. $\mathrm{NO}_{3}-\mathrm{N} / \mathrm{Cl}$ relationships at individual locations showed elevated concentrations of $\mathrm{NO}_{3}-\mathrm{N}$ due to fertilizers, while the spring waters were influenced by manure, septic effluent, or mixed sources. The presence of coliform supports the likelihood of animal or human waste influences on waters. Dissimilarities within their chemical fingerprints can be traced to aid in differentiating sources within the waters.
\end{abstract}

Keywords: karst; geochemistry; Nitrate; Chloride; springs; agriculture

\section{Introduction}

About $17 \%$ of the Earth's surface is covered by carbonate rocks [1] and between $7 \%-10 \%$ of the Earth's surface is considered karst [1,2]. Karst systems form through the dissolution of the bedrock, usually limestone $[1,3]$. The dissolution develops a high secondary porosity and permeability in the rock, allowing the karst unit to serve as an aquifer. Globally, 25\% of the population is dependent on karst aquifers for potable water [1,2]. With $20 \%$ of the land surface in the United States classified as karst, karst aquifers supply about $40 \%$ of the drinking water [2].

Numerous studies have examined the impact that humans have on karst areas (e.g., [4-12]). These studies highlight possible sources of pollutants, including the application of fertilizers and pesticides to fields [6,13,14], road salt [15], leaky septic systems [16,17], and wastewater [10,18,19]. Fertilizer application, either animal manure or synthetic fertilizer, is a significant source of nitrate as nitrogen $\left(\mathrm{NO}_{3}-\mathrm{N}\right)$ to aquifers [20]. Typically, $\mathrm{NO}_{3}-\mathrm{N}$ concentrations in non-contaminated groundwater are below $0.1 \mathrm{mg} / \mathrm{L}$, but can be as high as $3.0 \mathrm{mg} / \mathrm{L}$ [21]. In karst groundwater impacted by agriculture, 
$\mathrm{NO}_{3}-\mathrm{N}$ concentrations are generally above a $3 \mathrm{mg} / \mathrm{L}$ threshold but can exceed $10 \mathrm{mg} / \mathrm{L}$ [5-7,22], the drinking water standard defined by the United States Environmental Protection Agency (EPA) [23].

Chloride is an important element for animals and plants [24] and is a common byproduct of agricultural activity $[10,25,26]$. Agriculture is not the sole source for chloride. Elevated chloride concentrations measured in a karst aquifer in southwestern Illinois were attributed to septic system discharge and road salts [16]. Owing to its ability to lower the freezing temperature of water, chloride is used in de-icing agents applied during the winter [27]. At a secondary drinking water standard of $250 \mathrm{mg} / \mathrm{L}$ [23], chloride imparts a salty taste on the water [28] but is not associated with any health risks. In select karst areas, reported background concentrations are below $13 \mathrm{mg} / \mathrm{L}$ [5].

The use of animal manure or synthetic fertilizers on agricultural fields and effluent from septic systems introduce bacteria, viruses, pathogens, and hormones into both surface water and groundwater [4,16,29-31]. Elevated fecal coliform and bacterial concentrations in water are a concern because of the associated health risks [32]. Bacterial contamination of groundwater is a common occurrence in karst terrains owing to thin soils [32] and to bacteria being trapped in the epikarst $[29,33]$. In a study of soil in an agricultural area, Stoddard, et al. [34] observed the survival time of fecal coliform to be about six months after the spring application of manure and two months after fall application.

Other ions associated with agricultural activity are sodium, potassium [35], and sulfate [36,37]. Generally, groundwater contained in carbonate rocks has low concentrations of sodium, less than $2 \mathrm{mg} / \mathrm{L}$, and potassium, less than $0.6 \mathrm{mg} / \mathrm{L}[24,38]$. Elevated sodium concentrations indicate anthropogenic contamination, with human and animal manure being common anthropogenic sources [24]. A source of potassium in agricultural areas is potash $(\mathrm{KCl})$ [39], which is applied to fields as a potassium amendment to aid plant growth [24]. Sulfate can originate from several sources such as manure, household and industrial cleaning products, demolition waste, and industrial sulfuric acid [36]. Northwestern Illinois (Figure 1) has common karstic features, such as a shallow groundwater table, epikarst, sinkholes, and fractured bedrock $[38,40]$. Land use is dominated by agriculture, a combination of row crops and animal husbandry. As the area is dominated by carbonate rocks with limited impurities, there are slow rates of soil development [41], which contributes to the transport of anthropogenic contaminants into the karst aquifer. Manure is applied to area fields [42], which can be transported into streams during precipitation events and can infiltrate through the thin soils and epikarst into the groundwater systems [4,7].

Concerns about anthropogenic influences on the waters in northwest Illinois prompted an investigation examining the chemistry of both streams and springs. For a year, waters from six streams and five springs were sampled to assess anthropogenic impacts on the surface and groundwater. The work identifies differences in the geochemical signatures of the waters and recognizes that both surface water and groundwater have been impacted by anthropogenic sources.

\section{Materials and Methods}

\subsection{Geologic Setting}

The study focused on streams and springs located in the Driftless Area of northwestern Illinois, specifically an area in Jo Daviess County (Figure 1). The specific area was examined to provide background concentrations for the stream and spring waters prior to the building of a proposed confined animal feeding operation. Bedrock geology is comprised of the Galena-Platteville Group, fine-grained dolomites with limestone $[38,40,43]$. In the study region, the surficial geology is dominated by the Galena dolomite, a dense, low porosity to vuggy, high porosity unit $[43,44]$. Unaltered bedding planes range from very tight with no visible break to very thick with a layer of argillaceous material. The Galena dolomite is highly weathered and has typical karstic surface features, including sinkholes, karren, epikarst, and fractures [38,45]. The Galena dolomite is exposed in the northern portion of the study area in road cuts and along stream banks. However, exposure of the bedrock is limited due to the presence of a thin veneer of either loess, the Peoria Silt Formation, or Maquoketa Shale, in limited 
areas [46]. The Cahokia Formation, black stratified silt with some gravel of Quaternary age, is present in modern streams and creeks valleys [44]. Most of the soils, silt loams and silty clay loams, developed from the loess, with lower soil horizons having some residuum dolomitic limestone [47]. Soils have reported moderate hydraulic conductivity values, $4 \times 10^{-7} \mathrm{~m} / \mathrm{s}$ to $1 \times 10^{-5} \mathrm{~m} / \mathrm{s}$ [47].

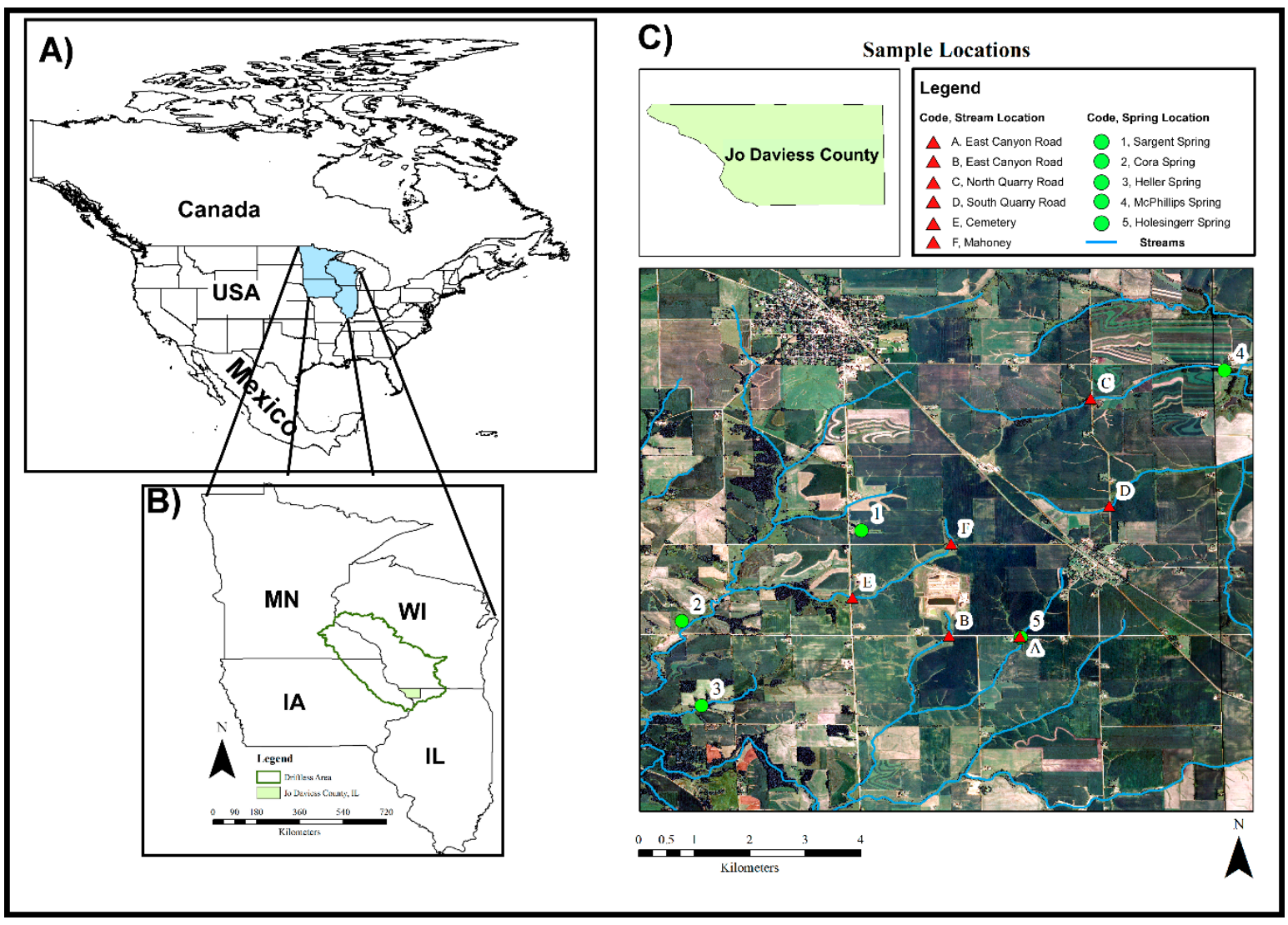

Figure 1. (A) Location of the study area within the USA. States shaded blue are presented in inset (B). (B) Location of the Driftless Area (outlined in green) of northeast Iowa (IA), northwest Illinois (IL), southeast Minnesota (MN), and southwest Wisconsin (WI). Jo Daviess County, the focal area for the study, is shaded green. (C). Locations of the streams (red triangles) and springs (green circles) sampled for this study.

Data for this research, six streams (East Canyon Rd., West Canyon Rd., Cemetery, Mahoney, North Quarry Rd., and South Quarry Rd.) and five springs (Cora, Heller, Holesinger, McPhillips, and Sargent springs) were collected in northwest Illinois (Figure 1). All of the sample locations were selected based upon access, which changed during the study. The sample locations of East Canyon Rd, West Canyon $\mathrm{Rd}$, and Cemetery are located in the Galena dolomite, with carbonate bedrock visible in the streambeds. A thin covering of Cahokia Formation overlies the Galena dolomite at East Canyon Rd, West Canyon $\mathrm{Rd}$, and Cemetery locations. The sample location of Mahoney is located on the edge of the Peoria Silt Formation with water then flowing across the Galena dolomite. Both the North Quarry Rd and South Quarry Rd sample locations are located in the Cahokia Formation with an exposure of the Galena dolomite near the sample locations. Streams in the area are classified as gaining streams, documented by an increase in the volume of water in downstream segments during base flow conditions. Streams are influenced by discharge from tile drains, with the greatest amount of influence occurring during and after precipitation events. Each of the streams had widths less than $2 \mathrm{~m}$ and depths less than $0.3 \mathrm{~m}$.

Four of the five springs, Cora, Heller, Holesinger, and Sargent, flowed directly out of the Galena dolomite, with pieces of Galena dolomite visible at these four springs. McPhillips Spring flowed out of the Cahokia Formation, and we interpret the source from the Galena dolomite given the geology of the 
area [44]. The flow rates of the five of the springs were low, less than 0.05 liters per second (L/s). None of the springs served as the main source of a sampled stream.

Agriculture is the dominant land use. Land cover data indicate that row crops, mainly corn and soybeans, are the dominant land cover type $(\sim 65 \%)$ in the study area. Pastures account for an additional $12 \%$ [48]. Two small urban areas, Warren with a population of about 1000 people and Nora with a population less than 200 people, are located within the study region.

\subsection{Methods}

Sampling of the streams started in September 2008 and continued until January 2010, excluding November 2008 to January 2009 when the streams were frozen. The locations of the streams were selected because of their accessibility and their proximity to agricultural operations. Sample collection at the streams was conducted between September 2008 and January 2010, with the exception of West Canyon Rd, which began September 2008, but stopped in July 2009 as a result of access. Water samples at the springs had different sampling intervals due to the fact that their locations and access were acquired at different times. Heller Spring was sampled from May to November 2009. Cora, McPhillips, and Sargent springs were sampled between June and November 2009. Holesinger Spring was sampled between June and November 2009.

Field parameters, $\mathrm{pH}$, temperature, dissolved oxygen (DO), specific conductance, and alkalinity, were measured and recorded at each location during the sampling events. An Oakton PC $10 \mathrm{~m}$ was used to measure $\mathrm{pH}$ and conductivity (specific conductance). A YSI Model 85 meter was used to measure DO and temperature. A HACH digital titrator (Model 16900) was used to measure alkalinity (Hach Method 8203). The probes were calibrated prior to each sampling. The concentrations of bicarbonate $\left(\mathrm{HCO}_{3}{ }^{-}\right)$were calculated from the alkalinity [24,49]. At each location, water samples were collected for analyses of major cations, major anions, biochemical oxygen demand (BOD), and total coliform. Water for the cations and anions were filtered in the field with a portable filtering unit using a $0.45 \mu \mathrm{m}$ filter; the filtered water was used to pre-rinse a Nalgene bottle prior to the final sample collection. The cation samples were acidified with nitric acid. During transport, both the cation and anion samples were stored in a cooler and were refrigerated until they were analyzed for major anion and cation concentrations. The following anions were analyzed with a Dionex ion chromatograph: chloride $\left(\mathrm{Cl}^{-}\right)$, sulfate $\left(\mathrm{SO}_{4}^{-}\right)$, and nitrate as nitrogen $\left(\mathrm{NO}_{3}-\mathrm{N}\right)$. An inductively coupled plasma mass spectrometer was used to analyze calcium $\left(\mathrm{Ca}^{2+}\right)$, magnesium $\left(\mathrm{Mg}^{2+}\right)$, and sodium $\left(\mathrm{Na}^{+}\right)$, while potassium $\left(\mathrm{K}^{+}\right)$was measured on an atomic adsorption spectrometer. Duplicate anion and cation samples were collected on each sampling trip and replicate ion samples were analyzed to ensure Quality Assurance/Quality Control (QA/QC). Overall, the average analytical error for the anions was $1.7 \%$ and the cation error was less than $7 \%$. The sum of all analyzed ions represented the total dissolved solids (TDS), which does not account for minor ions or organic ions. Geochemical data were analyzed using AquaChem ${ }^{\circledR}$ and its component PHREEQC [50] to derive saturation indices (SI) for calcite and dolomite.

BOD measurement followed the Standard Methods 5210 B. 5-Day BOD test [51] to determine the biochemical degradation of organic material [52], which can serve as a proxy for organic carbon. Natural bacteria populations were used in this study, with no bacterial seed or nitrification inhibitor added. After the incubation period, DO was measured using a YSI Model $85 \mathrm{~m}$. Total coliform was measured following Hach method 8074, which is designed for potable water. Total coliform samples were collected in Nasco WHIRL-PAK (Hach number 2075333). Field samples were filtered in sterilized filter funnels (Hach number 2831500). The filters were incubated for $24 \mathrm{~h}$ at $35.5^{\circ} \mathrm{C}$ in a Hach MEL/MF Portable Incubator Laboratory (Hach number 25699-00) in m-ColiBlue24 ${ }^{\circledR}$ broth (Hach number 2608442). Analyses for fecal coliform and E. coli would have been preferred, but resources were unavailable. 


\subsection{Statistical Analyses}

To assess potential differences between the stream and spring waters, the individual parameters were compared using a non-parametric Mann-Whitney rank sum test, with an alpha $(\alpha)$ of 0.05 .

\section{Results}

Data for the individual parameters for each stream and spring are presented in the supplementary data (Tables S1-S11) and figure (Figure S1); here a summary of the parameters has been presented.

\subsection{Field Parameters}

The $\mathrm{pH}$ values of the water in the streams were higher than those of the springs and exhibited less variation (Figure 2; Table 1). Measured stream water concentrations of both DO and BOD were higher than those measured in the spring waters and exhibited greater variability (Figure 2). Among the streams, DO concentrations varied between 5.4 and $18.5 \mathrm{mg} / \mathrm{L}$, while the spring waters displayed less variability, ranging between 1.9 and $9.3 \mathrm{mg} / \mathrm{L}$. Measured BOD in the stream water fluctuated between 0.9 to $12.8 \mathrm{mg} / \mathrm{L}$ (Figure 2), while the spring waters exhibited a narrower range between 1.21 to $5.97 \mathrm{mg} / \mathrm{L}$. Colonies of total coliform were observed in both the stream and spring waters. Higher colony counts were observed in the stream water as compared to the spring waters (Figure 2).

\subsection{Anions}

Chloride concentrations in the stream water ranged from 2.7 to $20.6 \mathrm{mg} / \mathrm{L}$ (Figure 2), with a median concentration of $13.5 \mathrm{mg} / \mathrm{L}$. Within the spring waters, measured chloride concentrations were between 7.6 and $28.1 \mathrm{mg} / \mathrm{L}$, with a median of $17.4 \mathrm{mg} / \mathrm{L}$. Measured stream water sulfate concentrations ranged from 7.7 to $43.4 \mathrm{mg} / \mathrm{L}$, while the spring waters had lower concentrations between 7.6 to 28.1 $\mathrm{mg} / \mathrm{L}$ (Figure 2). Bicarbonate concentrations in the stream waters were between 97.6 and $329.4 \mathrm{mg} / \mathrm{L}$ (Figure 2), while the spring waters had measured values from 175 to $403.8 \mathrm{mg} / \mathrm{L}$. $\mathrm{NO}_{3}-\mathrm{N}$ concentrations among the stream waters varied from 2.9 to $14.5 \mathrm{mg} / \mathrm{L}$, resulting in a median value of $9.3 \mathrm{mg} / \mathrm{L}$, which was below the $10 \mathrm{mg} / \mathrm{L}$ drinking water standard established by the EPA [23]. With the exception of one sample, all measured $\mathrm{NO}_{3}-\mathrm{N}$ concentrations in the spring waters were above the $10 \mathrm{mg} / \mathrm{L} \mathrm{MCL}$, ranging from 2.9 to $30.1 \mathrm{mg} / \mathrm{L}$. The median among all of the springs was $12.2 \mathrm{mg} / \mathrm{L} \mathrm{NO}_{3}-\mathrm{N}$.

\subsection{Cations}

Stream water calcium concentrations were between 20.9 and $77.7 \mathrm{mg} / \mathrm{L}$ (Figure 2); collectively, the median calcium concentration for the stream waters was $68.4 \mathrm{mg} / \mathrm{L}$. The spring waters experienced elevated calcium concentrations, ranging from 36.5 to $104.9 \mathrm{mg} / \mathrm{L}$. These higher concentrations resulted in a median concentration of $81.7 \mathrm{mg} / \mathrm{L}$. Magnesium concentrations for the stream waters were between 11.2 and $40.9 \mathrm{mg} / \mathrm{L}$, with a median value of $35.9 \mathrm{mg} / \mathrm{L}$. As with calcium, the magnesium concentrations measured within the spring waters were higher, ranging from 18.7 to $59.7 \mathrm{mg} / \mathrm{L}$ with a median value of $45.0 \mathrm{mg} / \mathrm{L}$. Sodium concentrations observed at the streams were between 2.8 and $17.4 \mathrm{mg} / \mathrm{L}$, resulting in a median sodium concentration of 8.4 for the stream waters. Similar sodium concentrations were measured in the spring waters, a range between 2.9 and $14.7 \mathrm{mg} / \mathrm{L}$, resulting in a median concentration for the spring waters of $8.9 \mathrm{mg} / \mathrm{L}$. Potassium concentrations measured in the stream waters were between 0.1 and $8.4 \mathrm{mg} / \mathrm{L}$, producing a median value of $0.9 \mathrm{mg} / \mathrm{L}$. Measured potassium concentrations in the spring waters were below detection limit up to $3.8 \mathrm{mg} / \mathrm{L}$ (Figure 2), which generated a median value of $0.7 \mathrm{mg} / \mathrm{L}$.

\subsection{Saturation Indices (SI)}

Both the stream waters and the spring waters were typically undersaturated with respect to both calcite and dolomite. The stream waters fluctuated from undersaturated to oversaturated in regards to calcite and dolomite saturation. Saturation indices for calcite $\left(\mathrm{SI}_{\mathrm{c}}\right)$ of the stream water ranged from 
-1.99 to 0.53 , with a median of -0.13 . Saturation indices for dolomite $\left(\mathrm{SI}_{\mathrm{d}}\right)$ of the stream water ranged from -4.00 to 1.01 , with a median of -0.39 . The spring waters were always undersaturated with respect to both calcite and dolomite. $\mathrm{SI}_{\mathrm{c}}$ values for the springs ranged between -1.39 to -0.32 , and $\mathrm{SI}_{\mathrm{d}}$ values were from -2.90 to -0.84 . The median values of $\mathrm{SI}_{\mathrm{c}}$ and $\mathrm{Si}_{\mathrm{d}}$ for the spring waters were -0.72 and 1.60 , respectively.

\subsection{Statistical Analysis}

The data for the individual parameters were not normally distributed, as indicated by failed tests for normality. The non-parametric Mann-Whitney rank sum tests was used to analyze the differences in the parameters between the streams and spring waters. The analyses of the parameters identified statistically significant differences for 13 of the 16 parameters (Table 1). Temperature, sodium, and potassium concentrations in the stream waters were not statistically different from the values in the spring water.

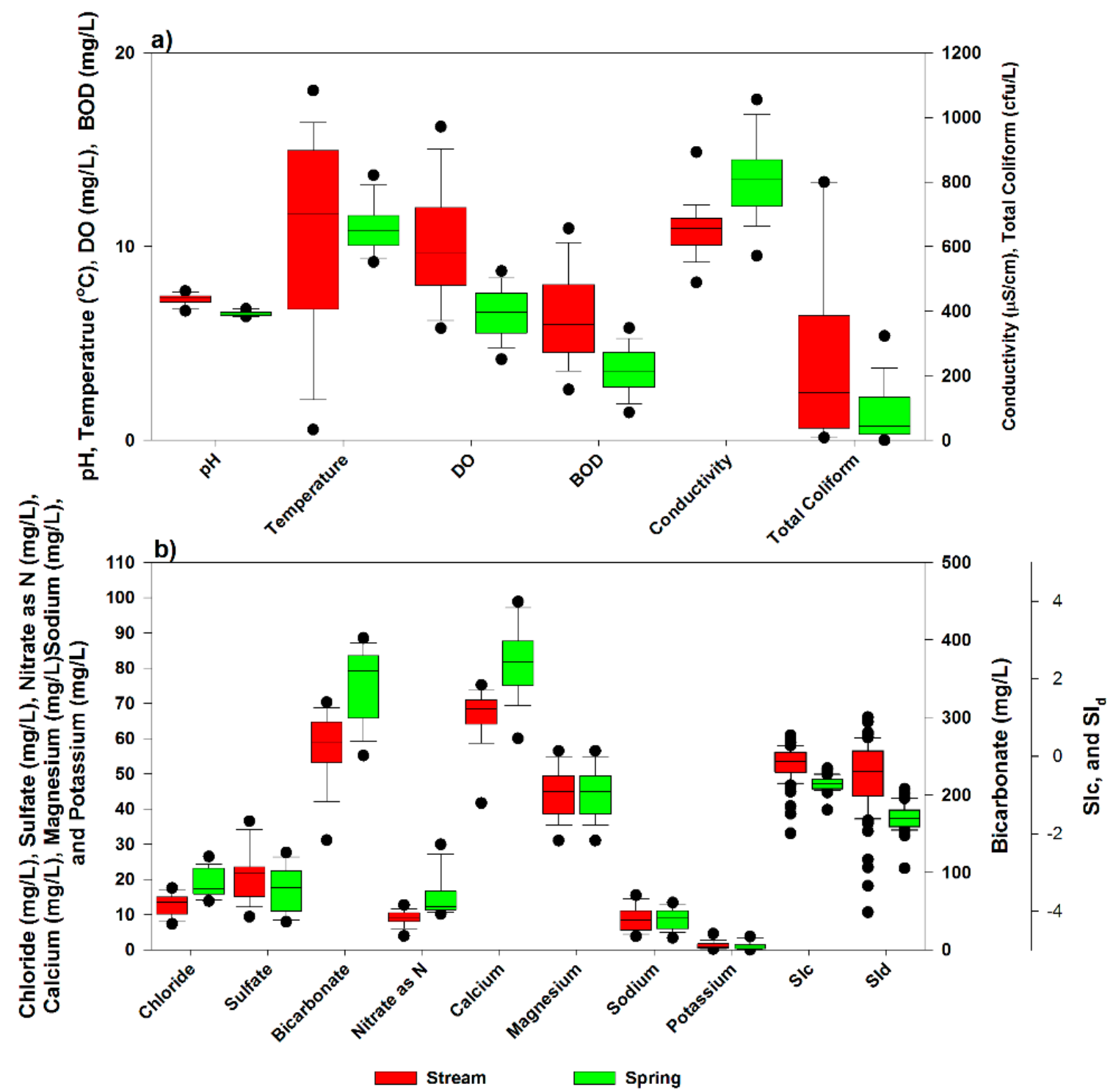

Figure 2. Box and whisker plots for the 16 water quality parameters measured among the streams (red) and springs (green). (a) Field parameters. (b) Chemical parameters. The ends of the boxes represent the 25th and 75th percentiles with the solid line at the median; the error bars depict the 10th and 90th percentiles and the points represent the 5 th and 95th percentiles. 
Table 1. $p$-values from the Mann-Whitney rank sum test between the stream and spring datasets. Cells shaded gray represent parameters with $p$-values less than 0.05 .

\begin{tabular}{cccc}
\hline Parameter & $\begin{array}{c}\text { Stream } \\
\text { Median }\end{array}$ & $\begin{array}{c}\text { Spring } \\
\text { Median }\end{array}$ & $p$-Value \\
\hline pH & 7.34 & 6.51 & $<0.001$ \\
Temperature- ${ }^{\circ}$ & 11.7 & 10.8 & 0.437 \\
Dissolved Oxygen-mg/L & 9.6 & 6.6 & $<0.001$ \\
Biological Oxygen & 6.0 & 3.6 & $<0.001$ \\
Demand-mg/L & 656 & 807 & $<0.001$ \\
Specific Conductance-S/cm & 148 & 43.5 & 0.001 \\
Total Coliform-CFU/100mL & 13.5 & 17.4 & $<0.001$ \\
Chloride-mg/L & 21.8 & 17.6 & 0.026 \\
Sulfate-mg/L & 268.4 & 359.9 & $<0.001$ \\
Bicarbonate-mg/L & 9.3 & 12.2 & $<0.001$ \\
Nitrate as nitrogen-mg/L & 68.4 & 81.7 & $<0.001$ \\
Calcium-mg/L & 35.9 & 45.0 & $<0.001$ \\
Magnesium-mg/L & 8.4 & 8.9 & 0.521 \\
Sodium-mg/L & 0.9 & 0.7 & 0.256 \\
Potassium-mg/L & -0.13 & -0.72 & $<0.001$ \\
SI-Calcite & -0.39 & -1.60 & $<0.001$ \\
SI-Dolomite & & & \\
\hline
\end{tabular}

\section{Discussion}

\subsection{Comparison: Stream and Spring Water Chemistry}

With 13 of the 16 parameters displaying statistical differences (Table 1), the stream and spring waters appear to be distinct. Temperature, sodium, and potassium were the only parameters that exhibited similar values between the stream and spring waters (Table 1; Figure 2). Although differences existed among the parameters, the stream and spring waters were classified as calcium-magnesium bicarbonate waters, occupying similar space on a Piper plot (Figure 3). Upon plotting the Na-Ca vs. TDS and $\mathrm{Cl}-\mathrm{HCO}_{3}$ vs. TDS relationships of the world's major surface waters, Gibbs [53] identified the dominant mechanisms controlling the water chemistry: atmospheric precipitation-chemistry is controlled by the ions sourced from precipitation; rock-water interaction-chemistry is controlled by dissolved ions from the rocks and soils of their basin; and evaporation-crystallization-chemistry is controlled by the concentration of ions as water evaporates from the source. The relationships of $\mathrm{Na}-\mathrm{Ca}$ vs. TDS and $\mathrm{Cl}-\mathrm{HCO}_{3}$ vs. TDS for the sampled waters plot within the rock dominated area, identifying rock-water interaction as the dominant mechanism defining the chemistry for both the stream waters and the spring waters (Figure 4). The geochemical signatures were consistent with the carbonate geology of the area. Combined concentrations for calcium and magnesium plotted against the combined concentrations of bicarbonate and sulfate plot above the equiline (Figure 5), signifying the role of carbonate weathering. While the ratios of the cations and anions were similar among the waters, the spring waters possessed higher concentrations of $\mathrm{Ca}^{2+}, \mathrm{Mg}^{2+}$, and $\mathrm{HCO}_{3}{ }^{-}$than the stream waters (Table 1, Figure 5). The higher concentrations imply a longer residence time and enhanced rock-water interaction (weathering) within the aquifer. The consistent temperatures of spring waters throughout the study (Figure 2) emphasized the thermal buffer capacity of the groundwater system, which implies longer residence times [54,55]. Differences between the waters extend beyond the concentration of the major ions. 


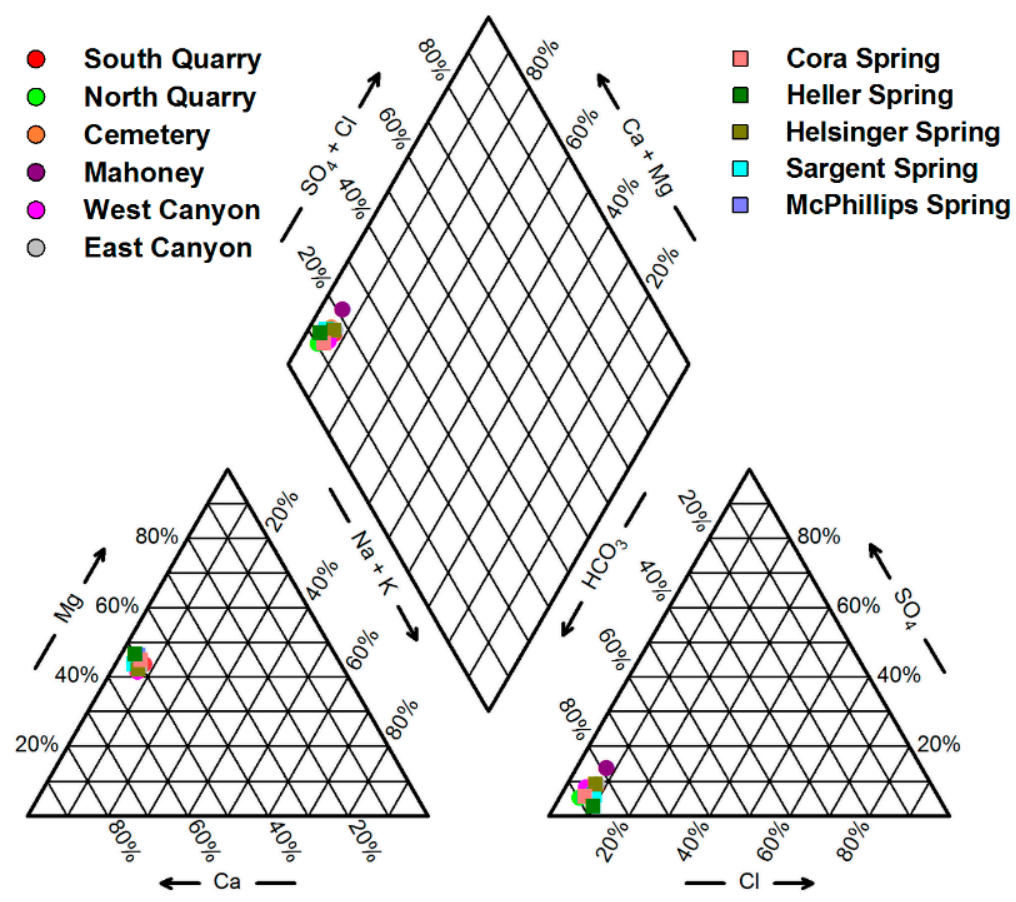

Figure 3. Piper plot showing the mean cation and anion compositions (\% meq/L) for the stream and spring waters from the various locations during the monitoring period.
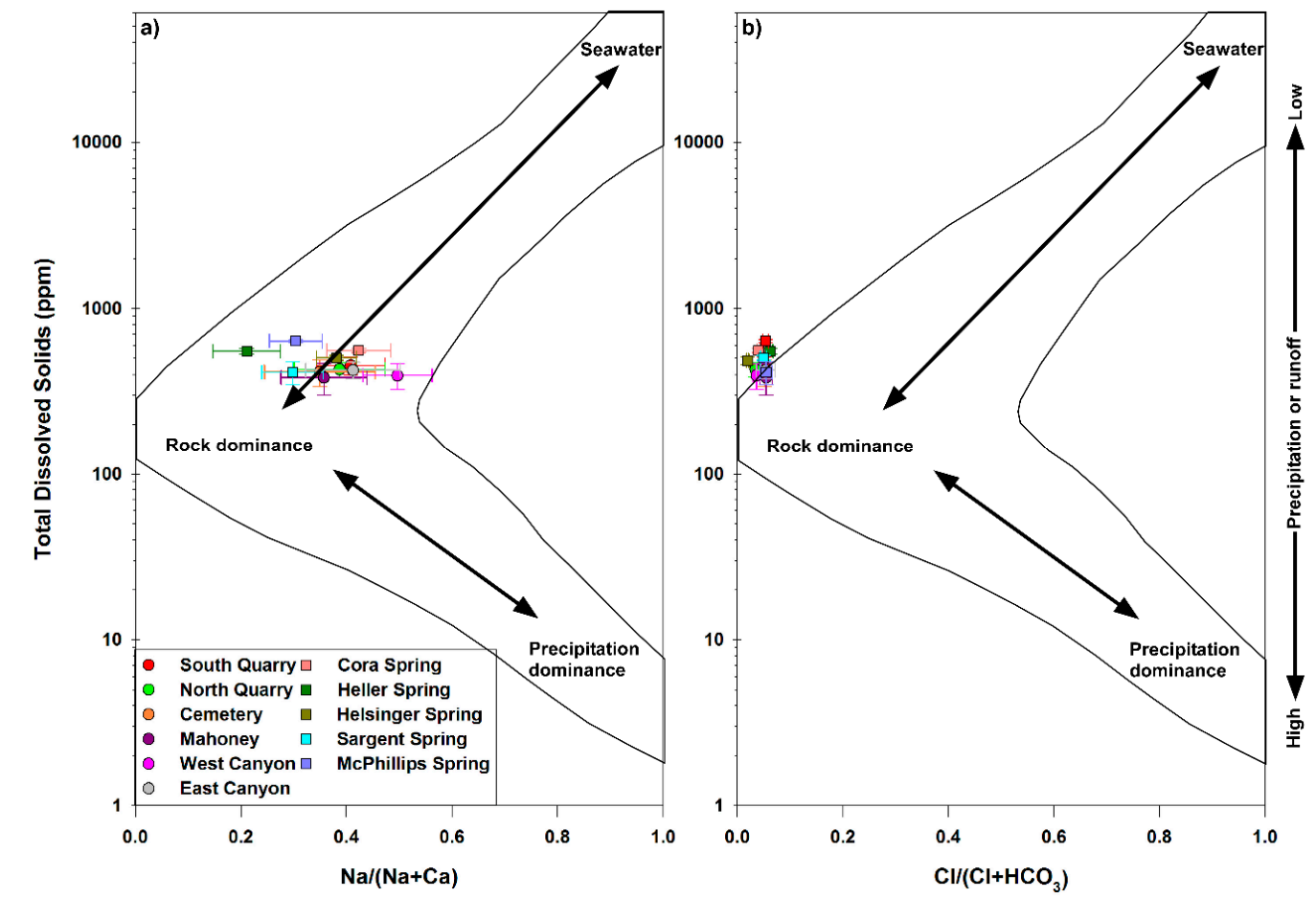

Figure 4. Gibbs diagrams identifying rock-water interaction as the dominant mechanism controlling the chemical composition of the waters. (a) Total dissolved solids (TDS) versus $\mathrm{Na} /(\mathrm{Na}+\mathrm{Ca}),(\mathbf{b})$ TDS versus $\mathrm{Cl} /\left(\mathrm{Cl}+\mathrm{HCO}_{3}\right)$. The lines serve as reference, defining the population of surface waters employed by Gibbs [53]. Samples plotting outside of the lines indicate chemistries that were not represented by the original population. 


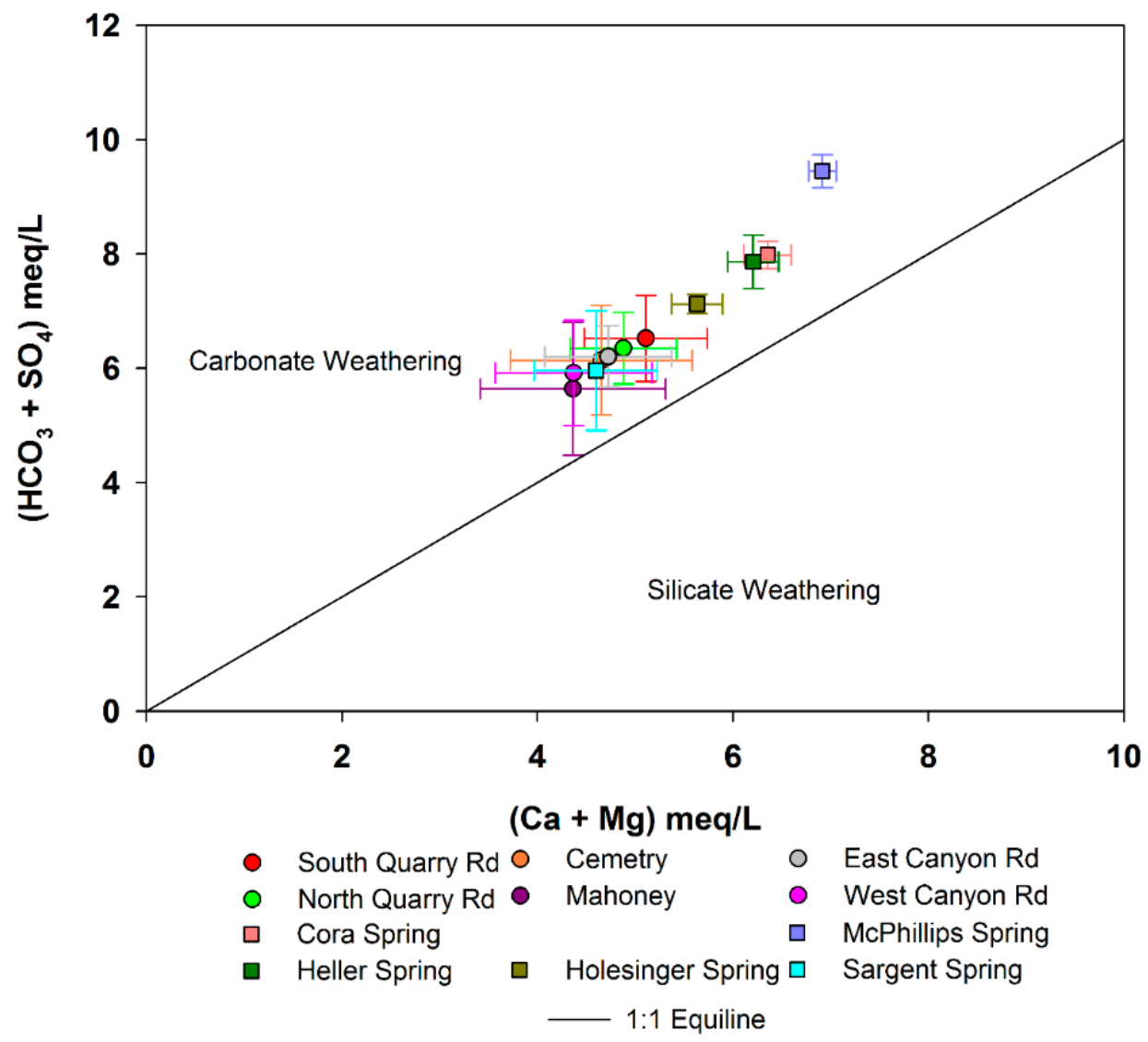

Figure 5. Calcium and magnesium (meq/L) versus bicarbonate and sulfate (meq/L) for the stream (circle) and spring (square) waters showing the carbonate weathering and silicate weathering zones defined by Datta and Tyagi [56] and Lakshmanan, et al. [57]. Points represent the mean value and the error bars indicate a standard deviation for the given location.

\subsection{Anthropogenic Influences}

Waters with chloride concentrations above $13 \mathrm{mg} / \mathrm{L}$ have been linked to the influence of anthropogenic practices [26]. Road salt, animal manure, septic effluent, and synthetic fertilizer have been documented to contribute $\mathrm{Cl}^{-}$to surface water and groundwater in karst areas $[5,26,45,58]$. Fertilizers used in the area include urea, anhydrous ammonia, diammonium phosphate, potash, and, on a more local basis, hog and dairy manure [38]. An examination of cations can help deduce the source of $\mathrm{Cl}^{-}$. Measured $\mathrm{Na}^{+}$in waters from a pure limestone source have been reported as below $2 \mathrm{mg} / \mathrm{L}$ [24]. In both the stream and groundwater, $\mathrm{Na}^{+}$concentrations were measured above the $2 \mathrm{mg} / \mathrm{L}$ threshold, with mean concentrations of 8.6 and $8.7 \mathrm{mg} / \mathrm{L}$, respectively. With $\mathrm{Na}^{+}$concentrations above the $2 \mathrm{mg} / \mathrm{L}$, a non-natural $\mathrm{Na}^{+}$source was posited. With $\mathrm{Na} / \mathrm{Cl}$ ratios near or above 1 (Figure 6), dissolution of halite was inferred for all of the stream waters and the waters of Cora Spring and Holesinger. The $\mathrm{Na}-\mathrm{Cl}$ relationship for the streams suggested that halite was the source of the ions, which could be indicative of road salts contamination $[3,5,26,27,45,58]$. While $\mathrm{Cl}^{-}$concentrations above the $13 \mathrm{mg} / \mathrm{L}$ may indicate impacts of road salt, typical chloride concentrations of streams impacted by road salt exceed $100 \mathrm{mg} / \mathrm{L}$, especially in the winter months [27,45]. Seasonal concentration spikes were not observed and none of the measured $\mathrm{Cl}^{-}$concentrations approached levels reflecting the impact by road salt, suggesting road salts were not the prominent anthropogenic source. The highest concentration measured in a stream was $20.5 \mathrm{mg} / \mathrm{L}$, with no significant elevation during the winter months. Within the spring waters the maximum measured $\mathrm{Cl}^{-}$concentration was $26.7 \mathrm{mg} / \mathrm{L}$. Despite the $\mathrm{K} / \mathrm{Cl}$ ratios for all locations below 0.5 (Figure 6), potash fertilizers appear to have impacted the springs or streams. Stream water from South Quarry and spring waters from Holesinger and McPhillips Spring were 
continuously above the $0.6 \mathrm{mg} / \mathrm{L}$ the reported background concentration [59] (Figure 2). Waters from the other streams had higher $\mathrm{K}^{+}$in the spring and fall during non-growing season. Most of the spring water samples were below the $0.6 \mathrm{mg} / \mathrm{L}$ threshold, but each spring experienced one or two elevated concentrations. Overall, road salts and potash appear to contribute to the elevated $\mathrm{Cl}^{-}$concentrations. However, the presence of total coliform during most sampling indicated manure or septic effluent serves as a significant source [60].

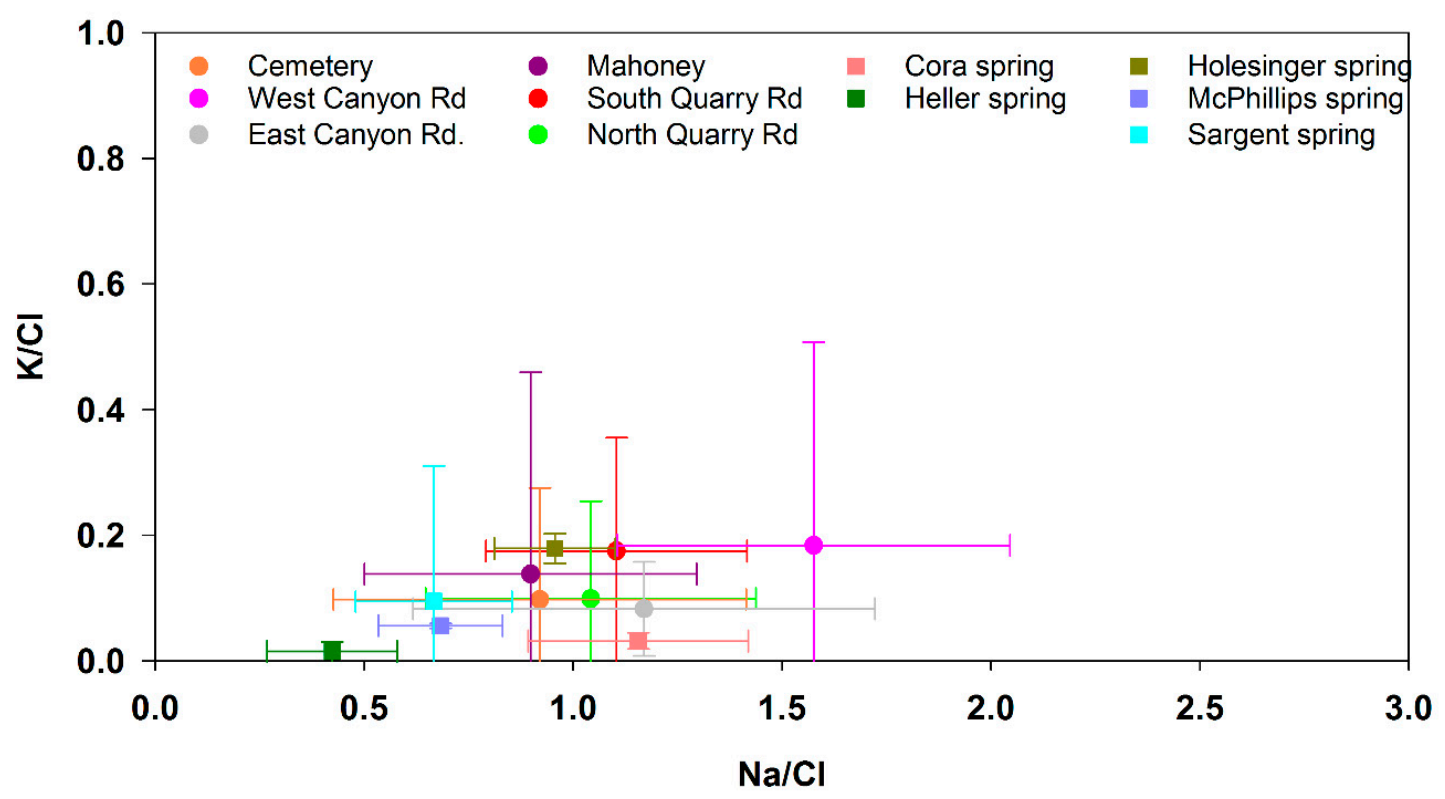

Figure 6. Molar $\mathrm{Na} / \mathrm{Cl}$ ratios versus molar $\mathrm{K} / \mathrm{Cl}$ ratios for the stream (circle) and spring (square) waters. Molar $\mathrm{Na} / \mathrm{Cl}$ ratios close to 1.0 suggest halite influence while molar $\mathrm{K} / \mathrm{Cl}$ ratios close to 1 support fertilizer, potash $(\mathrm{KCl})$, influence. Points represent the mean value and the error bars indicate a standard deviation for the given location.

Nitrate is a common groundwater pollutant symptomatic of anthropogenic sources, i.e. agricultural, domestic sewages, and animal manure $[61,62]$ and elevated concentrations are common in karst aquifers $[5,7,22,63,64]$. In karst areas of Illinois, elevated $\mathrm{NO}_{3}-\mathrm{N}$ concentrations have been reported in areas impacted by animal manure or domestic sewage $[6,12,16,17,59,65]$. Background $\mathrm{NO}_{3}-\mathrm{N}$ concentrations reported for karst aquifers of southwest Illinois are typically equal to or less than $2.5 \mathrm{mg} / \mathrm{L}[5,6,16]$, with concentrations above that level indicative of anthropogenic influences [26]. All of the springs and streams had $\mathrm{NO}_{3}-\mathrm{N}$ concentrations above the background $\mathrm{NO}_{3}-\mathrm{N}$ concentration. With the exception of Mahoney and South Quarry Rd., all of the springs and streams had measured $\mathrm{NO}_{3}-\mathrm{N}$ concentrations above the drinking water standard of $10 \mathrm{mg} / \mathrm{L}$ [23] at some point during the monitoring period. The $\mathrm{NO}_{3}-\mathrm{N}$ concentrations recorded during this study were higher than those reported in other areas of Illinois $[12,16,59,66]$. Ratios of nitrate as nitrogen to chloride $\left(\mathrm{NO}_{3}-\mathrm{N} / \mathrm{Cl}\right)$ can be used to identify distinct vectors [26]. As such, the $\mathrm{NO}_{3}-\mathrm{N} / \mathrm{Cl}$ ratios at the locations suggested that the streams have experienced elevated concentrations of $\mathrm{NO}_{3}-\mathrm{N}$ as a result of the application of synthetic fertilizers, while the springs have been impacted by animal manure, septic effluent, or mixed sources (Figure 7). Anthropogenic impacts are common in other karst springs of Illinois, where fertilizer, animal manures, and septic systems are identified as the primary source of contamination $[12,16,59,65]$. Septic effluent and manures appear to be the source of the $\mathrm{Na}^{+}$and $\mathrm{Cl}^{-}$, reflecting the influence of salts commonly added to animal feed to enhance the feed flavors and maintain cation-anion balance in the diet $[67,68]$. The presence of coliform colonies supports the sources as human or animal waste $[17,30,31,69]$. 


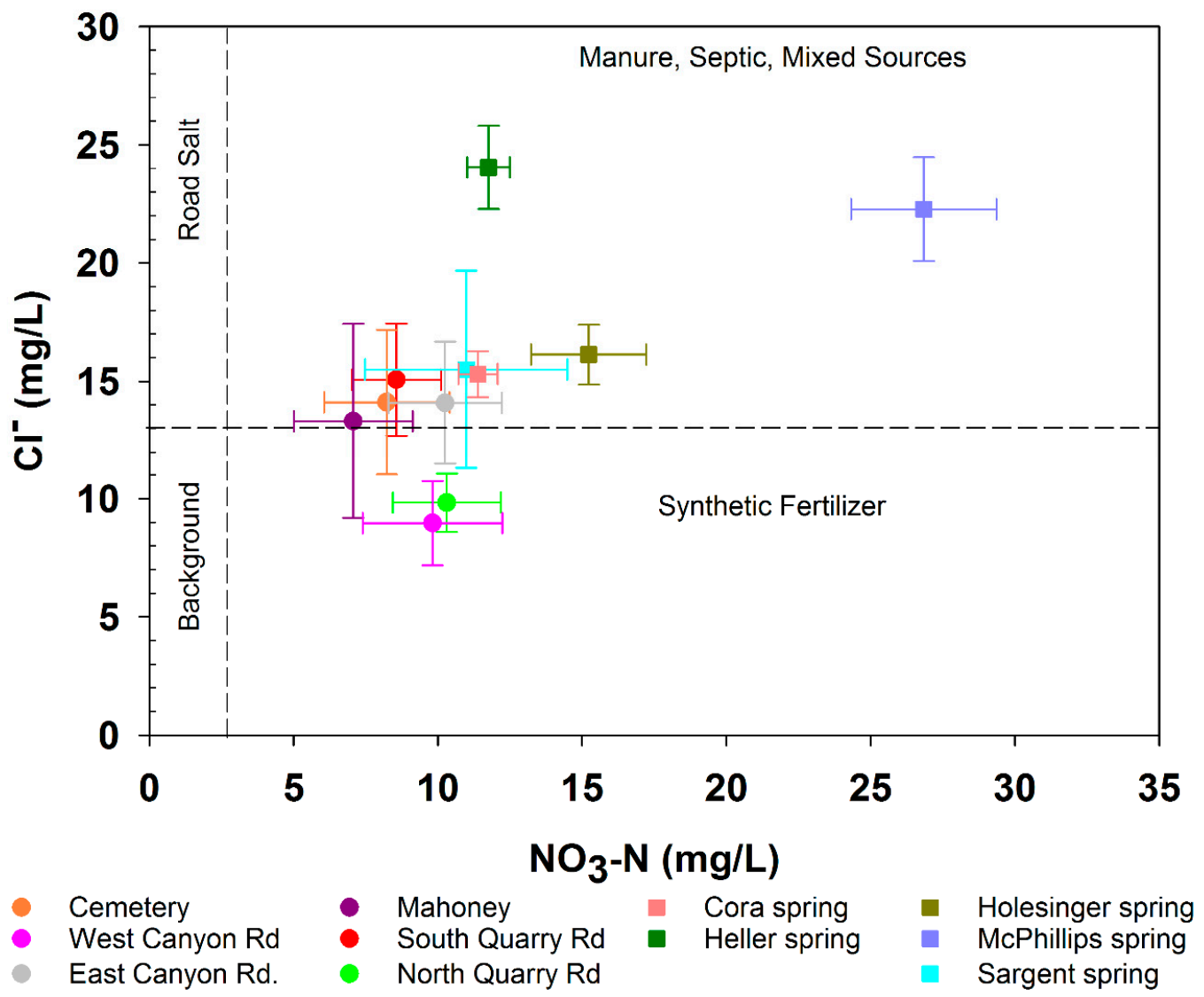

Figure 7. $\mathrm{NO}_{3}-\mathrm{N}$ versus $\mathrm{Cl}^{-}$for the stream waters (circles) and spring waters (squares). Dashed lines represent background values [26,70]. Classifications defined by Taylor, et al. [59].

An additional anthropogenic source of nitrate may be the process of nitrification. $\mathrm{NO}_{3}-\mathrm{N}$ concentrations in the spring waters were higher than those measured in the stream waters. While processes within stream benthic sediments could contribute to this disparity between surface/sub-surface water [71-74], nitrification within the karst aquifer may contribute to the higher values. It was reported by [63] that nitrification was occurring in the Edwards Aquifer but not in the surface streams. While land use in the Edwards Aquifer was predominantly suburban to urban, primary $\mathrm{NO}_{3}-\mathrm{N}$ sources were believed to be fertilizers and human-animal waste. However, a review of the nitrogen mass balance revealed a deficit of $\mathrm{NO}_{3}{ }^{-}$, indicating an additional source of $\mathrm{NO}_{3}{ }^{-}$ in the karst aquifer was needed. Comparing the recharge to the system with the discharge from the system, an increase in $\mathrm{NO}_{3}-\mathrm{N}$ corresponding with both the consumption of $\mathrm{DO}$ and a decrease in total organic carbon (TOC) was observed. The reduction of DO and TOC was attributed to the microbial nitrification process. The conditions reported in the Edwards Aquifer are similar to those observed in the northwest Illinois system. The measured BOD in the spring waters were low and may indicate the depletion of organic carbon during the nitrification process within the aquifer. Additionally, the spring waters had lower DO concentrations compared to the surface waters. The primary source of the organic carbon would be the manures and sewage effluent, which would suggest a secondary effect of the anthropogenic influences. To address the hypothesis of nitrification within the aquifer, future investigation examining additional nitrogen species and nitrogen isotopes would be warranted to develop a nitrogen mass balance for the area.

\section{Conclusions}

While there were statistical differences in the spring and stream water quality parameters, the similar water type, calcium-magnesium bicarbonate, highlights water-rock interaction as the 
controlling process defining the geochemistry of the stream and spring waters. This alteration in the stream and spring water parameters was especially true among those parameters that can be influenced by human activities.

The elevated $\mathrm{NO}_{3}-\mathrm{N}, \mathrm{Cl}^{-}, \mathrm{Na}^{+}$, and $\mathrm{K}^{+}$concentrations indicate that anthropogenic activities have influenced the overall water quality of both the streams and the springs. Fertilizers, manure, sewage effluent, road salt, and pesticides are potential sources of elevated ions. The presence of coliform colonies further support animal manures or septic effluent as anthropogenic influences on the water. Higher $\mathrm{NO}_{3}-\mathrm{N}$ concentrations in the spring water could be attributed to nitrification within the karst aquifer. Nitrification lowers DO and requires organic carbon. As compared to surface waters, the lower DO concentrations coupled with the lower BOD concentrations, which can serve as proxy for organic carbon, measured in groundwater suggest nitrification processes are occurring.

This research provides further insight into the vulnerability of karst aquifers to anthropogenic pollutants. The shallow water table, near surface bedrock, and lack of soil due to the limited impurities in the carbonate bedrock creates an optimal environment for pollutants to migrate to the subsurface as seen by the elevated major ion and coliform values. Anthropogenic practices that take place within karst areas should consider this information and adjust practices when possible to mitigate the effects on karst aquifers.

Supplementary Materials: The following are available online at http:/ www.mdpi.com/2076-3263/9/4/148/s1: Table S1: Field and laboratory measurements for East Canyon Rd. Table S2: Field and laboratory measurements for West Canyon Rd. Table S3: Field and laboratory measurements for Mahoney. Table S4: Field and laboratory measurements for Cemetery. Table S5: Field and laboratory measurements for North Quarry Rd. Table S6: Field and laboratory measurements for South Quarry Rd. Table S7: Field and laboratory measurements for Cora spring. Table S8: Field and laboratory measurements for Heller spring. Table S9: Field and laboratory measurements for Holesinger spring. Table S10: Field and laboratory measurements for McPhillips spring. Table S11: Field and laboratory measurements for Sargent spring. Figure S1. Box and whisker plots for the 16 water quality parameters measured at the individual streams and springs.

Author Contributions: B.M. and E.W.P. conceived and designed the experiments; B.M. collected and analyzed the water samples under E.W.P. supervision. B.M., E.W.P., J.H., A.O, P.O., I.R., and A.W. analyzed the data. B.M. and E.W.P. wrote the initial paper. B.M., E.W.P., J.H., A.O, P.O., I.R., and A.W. revised and edited the paper.

Funding: This research was funded by the Illinois Groundwater Association through a student grant to BM.

Acknowledgments: The authors thank the property owners that provided access to the springs sampled for this project. The authors thank the three reviewers for their critiques that improved the paper.

Conflicts of Interest: The authors declare no conflict of interest. The funders had no role in the design of the study; in the collection, analyses, or interpretation of data; in the writing of the manuscript; or in the decision to publish the results.

\section{References}

1. Gillieson, D.S. Caves: Processes, Development, and Management; Blackwell Publishers: Oxford, UK, 1996 ; p. 324.

2. Green, R.T.; Painter, S.L.; Sun, A.; Worthington, S.R.H. Groundwater Contamination in Karst Terranes. Waterairsoil Pollut. Focus 2006, 6, 157-170. [CrossRef]

3. Palmer, A.N. Cave Geology; Cave Books: Dayton, OH, USA, 2007.

4. Gupta, S.; Munyankusi, E.; Moncrief, J.; Zvomuya, F.; Hanewall, M. Tillage and manure application effects on mineral nitrogen leaching from seasonally frozen soils. J. Environ. Qual. 2004, 33, 1238-1246. [CrossRef]

5. Angel, J.C.; Peterson, E.W. Nitrates in karst systems: Comparing impacted systems to a relatively unimpacted system. J. Geogr. Geol. 2015, 7, 65-76. [CrossRef]

6. Panno, S.V.; Kelly, W.R. Nitrate and herbicide loading in two groundwater basins of Illinois' sinkhole plain. J. Hydrol. 2004, 290, 229-242. [CrossRef]

7. Peterson, E.; Davis, R.; Brahana, J.; Orndorff, H. Movement of nitrate through regolith covered karst terrane, northwest Arkansas. J. Hydrol. 2002, 256, 35-47. [CrossRef]

8. Kresic, N.; Papic, P.; Golubovic, R. Elements of groundwater protection in a karst environment. Environ. Geol. Water Sci. 1992, 20, 157-164. [CrossRef] 
9. Long, A.J.; Sawyer, J.F.; Putnam, L.D. Environmental tracers as indicators of karst conduits in groundwater in South Dakota, USA. Hydrogeol. J. 2008, 16, 263-280. [CrossRef]

10. Mooers, H.D.; Alexander, E.C., Jr. Contribution of spray irrigation of wastewater to groundwater contamination in the karst of southeastern Minnesota, USA. Appl. Hydrogeol. 1994, 2, 34-44. [CrossRef]

11. Nguyet, V.T.M.; Goldscheider, N. Tracer tests, hydrochemical and microbiological investigations as a basis for groundwater protection in a remote tropical mountainous karst area, Vietnam. Hydrogeol. J. 2006, 14, 1147-1159. [CrossRef]

12. Hackley, K.C.; Panno, S.V.; Hwang, H.H.; Kelly, W.R. Groundwater Quality of Springs and Wells of the Sinkhole Plain in Southwestern Illinois; Illinois State Geological Survey: Champaign, IL, USA, 2007; Volume 570, p. 39.

13. Crain, A.S. Pesticides and Nutrients in Karst Springs in the Green River basin, Kentucky, May-September 2001; 133-01; United States Geological Survey: Louisville, KY, USA, 2002; p. 3.

14. Taraba, J.; Dinger, J.; Sendlein, L.; Felton, G. Land use impacts on water quality in small karst agricultural watersheds. In Proceedings of the Karst-Water Environment Symposium, Roanoke, VR, USA, 30-31 October 1997; p. 127.

15. Robinson, H.K.; Hasenmueller, E.A.; Chambers, L.G. Soil as a reservoir for road salt retention leading to its gradual release to groundwater. Appl. Geochem. 2017, 83, 72-85. [CrossRef]

16. Dodgen, L.K.; Kelly, W.R.; Panno, S.V.; Taylor, S.J.; Armstrong, D.L.; Wiles, K.N.; Zhang, Y.; Zheng, W. Characterizing pharmaceutical, personal care product, and hormone contamination in a karst aquifer of southwestern Illinois, USA, using water quality and stream flow parameters. Sci. Total Environ. 2017, 578, 281-289. [CrossRef] [PubMed]

17. Kelly, W.R.; Panno, S.V.; Hackley, K.C.; Martinsek, A.T.; Krapac, I.G.; Weibel, C.P.; Storment, E.C. Bacteria Contamination of Groundwater in a Mixed Land-Use Karst Region. Water Qual. Expo. Health 2009, 1, 69-78. [CrossRef]

18. Katz, B.G.; Griffin, D.W. Using chemical and microbiological indicators to track the impacts from the land application of treated municipal wastewater and other sources on groundwater quality in a karstic springs basin. Environ. Geol. 2008, 55, 801-821. [CrossRef]

19. Mahler, B.J.; Personne, J.C.; Lods, G.F.; Drogue, C. Transport of free and particulate-associated bacteria in karst. J. Hydrol. 2000, 238, 179-193. [CrossRef]

20. Maticic, B. The impact of agriculture on ground water quality in Slovenia: Standards and strategy. Agric. Water Manag. 1999, 40, 235-247. [CrossRef]

21. Liu, A.; Ming, J.; Ankumah, R.O. Nitrate contamination in private wells in rural Alabama, United States. Sci. Total Environ. 2005, 346, 112-120. [CrossRef] [PubMed]

22. Boyer, D.G.; Pasquarell, G.C. Nitrate concentrations in karst springs in an extensively grazed area. Water Resour. Bull. 1995, 31, 729-736. [CrossRef]

23. United States Environmental Protection Agency. 2011 Edition of the Drinking Water Standards and Health Advisories; U.S. Environmental Protection Agency: Washington, DC, USA, 2011; p. 18.

24. Hem, J.D. Study and Interpretation of the Chemical Characteristics of Natural Water; 1473; U.S. Department of the Interior; U.S. Geological Survey: Washington, DC, USA, 1959.

25. Link, M.L.; Inman, D.L. Ground Water Monitoring at Livestock Waste Control Facilities in NEBRASKA; Ground Water Unit, Water Quality Assessment Section, Nebraska Department of Environmental Quality: Lincoln, NE, USA, 2003.

26. Panno, S.V.; Hackley, K.C.; Hwang, H.H.; Greenberg, S.E.; Krapac, I.G.; Landsberger, S.; O’Kelly, D.J. Characterization and identification of $\mathrm{Na}-\mathrm{Cl}$ sources in ground water. Ground Water 2006, 44, $176-187$. [CrossRef]

27. Kelly, W.R. Long-term trends in chloride concentrations in shallow aquifers near Chicago. Ground Water 2008, 46, 772-781. [CrossRef]

28. Quade, D.; Libra, R.; Seigley, L.; Bettis, E. Groundwater monitoring at an earthen manure-storage structure. Iowa Dep. Nat. Resour. Hogsbogslogs Quat. Depos. Environ. Geol. Des Moines Lobe Geol. Surv. Bur. Guideb. Ser. 1996, 18, 141-153.

29. Davis, R.K.; Hamilton, S.; Brahana, J.V. Escherichia coli survival in mantled karst springs and streams, northwest Arkansas Ozarks, USA. J. Am. Water Resour. Assoc. 2005, 41, 1279-1287. [CrossRef]

30. Peterson, E.; Davis, R.; Orndorff, H. 17b-estradiol as an indicator of animal waste contamination in mantled karst aquifers. J. Environ. Qual. 2000, 29, 826-834. [CrossRef] 
31. Ting, T.E.; Davis, R.K.; Brahana, J.V.; Hays, P.D.; Thoma, G. Application of Multiple Tracers to Characterize Complex Sediment and Pathogen Transport in Karst. In Proceedings of the U.S. Geological Survey Karst Interest Group Proceedings, Rapid City, SD, USA, 12-15 September 2005; p. 114.

32. Howell, J.M.; Coyne, M.S.; Cornelius, P. Fecal Bacteria in Agricultural Waters of the Bluegrass Region of Kentucky. J. Environ. Qual. 1995, 24, 411-419. [CrossRef]

33. Massei, N.; Lacroix, M.; Wang, H.Q.; Dupont, J.P. Transport of particulate material and dissolved tracer in a highly permeable porous medium: Comparison of the transfer parameters. J. Contam. Hydrol. 2002, 57, 21-39. [CrossRef]

34. Stoddard, C.S.; Coyne, M.S.; Grove, J.H. Fecal bacteria survival and infiltration through a shallow agricultural soil: Timing and tillage effects. J. Environ. Qual. 1998, 27, 1516-1523. [CrossRef]

35. Griffioen, J. Potassium adsorption ratios as an indicator for the fate of agricultural potassium in groundwater. J. Hydrol. 2001, 254, 244-254. [CrossRef]

36. Bottrell, S.; Tellam, J.; Bartlett, R.; Hughes, A. Isotopic composition of sulfate as a tracer of natural and anthropogenic influences on groundwater geochemistry in an urban sandstone aquifer, Birmingham, UK. Appl. Geochem. 2008, 23, 2382-2394. [CrossRef]

37. Einsiedl, F.; Mayer, B. Hydrodynamic and Microbial Processes Controlling Nitrate in a Fissured-Porous Karst Aquifer of the Franconian Alb, Southern Germany. Environ. Sci. Technol. 2006, 40, 6697-6702. [CrossRef]

38. Panno, S.V.; Luman, D.E. Assessment of the Geology and Hydrogeology of Two Sites for a Proposed Large Dairy Facility in Jo Daviess County Near Nora, IL; Illinois State Geological Survey, Institute of Natural Resource Sustainability, University of Illinois: Champaign, IL, USA, 2008.

39. Bray, R.H. Soil-plant relations: I. The quantitative relation of exchangeable potassium to crop yields and to crop response to potash additions. Soil Sci. 1944, 58, 305-324. [CrossRef]

40. Panno, S.V.; Luman, D.E.; Kolata, D.R. Characterization of Karst Terrain and Regional Tectonics Using Remotely Sensed Data in Jo Daviess County, Illinois; Illinois State Geological Survey: Champaign, IL, USA, 2015; p. 29.

41. Stiles, C.A.; Stensvold, K.A. Loess contribution to soils forming on dolostone in the Driftless Area of Wisconsin. Soil Sci. Soc. Am. J. 2008, 72, 650-659. [CrossRef]

42. Schneider, J.; Nikodem, L.; Rumpler, J. Factory Farms, Fouled Waters: How Industrial Livestock Operations Pollute Illinois Rivers, Lakes and Streams; Environment Illinois Research \& Education Center: Chicago, IL, USA, 2014; p. 29.

43. Willman, H.B.; Kolata, D.R. The Platteville and Galena Groups in Northern Illinois; Illinois State Geological Survey: Urbana, IL, USA, 1978; p. 75.

44. Maas, B.; Peterson, E.W.; Malone, D.; Nelson, R. Surficial Geology of the Warren 7.5 Minute Quadrangle, JoDaviess and Stephenson Counties, Illinois. In EDMAP; Illinois State Geological Survey: Champaign, IL, USA, 2010.

45. Lax, S.M.; Peterson, E.W.; Van der Hoven, S. Quantifying Stream chloride concentrations as a function of land-use. Environ. Earth Sci. 2017, 76, 12. [CrossRef]

46. McGarry, C.S. Bedrock Geology of Boone and Winnebago Counties, Illinois; Illinois State Geological Survey: Champaign, IL, USA, 2000.

47. Tegeler, R.A. Soil Survey of Jo Daviess County, Illinois; United States Department of Agriculture: Buckeye, AZ, USA, 1996; p. 224.

48. Homer, C.H.; Fry, J.A.; Barnes, C.A. The National Land Cover Database; United States Geological Survey: Reston, VR, USA, 2012.

49. White, W.B. Geomorphology and Hydrology of Karst Terrains; Oxford University Press: New York, NY, USA, 1988; p. 464.

50. Parkhurst, D.L.; Appelo, C. User's guide to PHREEQC (version 2)-a computer program for speciation, batch-reaction, one-dimensional transport, and inverse geochemical calculations. Water-Resour. Investig. Rep. 1999, 99, 312.

51. American Public Health Association. 5210 B. 5-Day BOD Test. In Standard Methods for the Examination of Water and Wastewater, 21st ed.; American Public Health Association: Washington, DC, USA, 2005; p. 1368.

52. Water Environmental Federation; American Public Health Association. Standard Methods for the Examination of Water and Wastewater; American Public Health Association: Washington, DC, USA, 2005; Volume 1015, pp. 49-51.

53. Gibbs, R.J. Mechanisms Controlling World Water Chemistry. Science 1970, 170, 1088-1090. [CrossRef] [PubMed] 
54. Doucette, R.; Peterson, E.W. Identifying water sources in a karst aquifer using thermal signatures. Environ. Earth Sci. 2014, 72, 5171-5182. [CrossRef]

55. Luhmann, A.J.; Covington, M.D.; Peters, A.J.; Alexander, S.C.; Anger, C.T.; Green, J.A.; Runkel, A.C.; Alexander, E.C., Jr. Classification of Thermal Patterns at Karst Springs and Cave Streams. Ground Water 2010, 49. [CrossRef] [PubMed]

56. Datta, P.; Tyagi, S. Major ion chemistry of groundwater in Delhi area: Chemical weathering processes and groundwater flow regime. J. Geol. Soc. India 1996, 47, 179-188.

57. Lakshmanan, E.; Kannan, R.; Kumar, M.S. Major ion chemistry and identification of hydrogeochemical processes of ground water in a part of Kancheepuram district, Tamil Nadu, India. Environ. Geosci. 2003, 10, 157-166. [CrossRef]

58. Lax, S.; Peterson, E.W. Characterization of chloride transport in the unsaturated zone near salted road. Environ. Geol. 2009, 58, 1041-1049. [CrossRef]

59. Taylor, S.J.; Kelly, W.R.; Panno, S.V.; Weck, R.; Zheng, W.; Zhang, Y.; Liu, W.-T. Karst Groundwater Contaminants in Western Illinois: Comparison of Current Conditions with Historical data; Illinois Natural History Survey, Prairie Research Institute, University of Illinois: Champaign, IL, USA, 2014; p. 53.

60. Geldreich, E.E. Microbial Quality of Water Supply in Distribution Systems; CRC Press: Boca Raton, FL, USA, 1996.

61. Janardhana Raju, N.; Shukla, U.K.; Ram, P. Hydrogeochemistry for the assessment of groundwater quality in Varanasi: A fast-urbanizing center in Uttar Pradesh, India. Environ. Monit. Assess. 2011, 173, 279-300. [CrossRef]

62. Yuan, J.; Xu, F.; Deng, G.; Tang, Y.; Li, P. Hydrogeochemistry of Shallow Groundwater in a Karst Aquifer System of Bijie City, Guizhou Province. Water 2017, 9, 625. [CrossRef]

63. Musgrove, M.; Opsahl, S.P.; Mahler, B.J.; Herrington, C.; Sample, T.L.; Banta, J.R. Source, variability, and transformation of nitrate in a regional karst aquifer: Edwards aquifer, central Texas. Sci. Total Environ. 2016, 568, 457-469. [CrossRef]

64. Peterson, E.W.; Davis, R.K.; Brahana, J.V. The use of regression analysis to predict nitrate-nitrogen concentrations in springs of Northwest Arkansas. In Groundwater Flow and Contaminant Transport in Carbonate Aquifers; Sasowsky, I.D., Wicks, C.M., Eds.; A.A Balkema: Rotterdam, The Netherlands, 2000; pp. $43-63$.

65. Panno, S.V.; Kelly, W.R. Driftless Area Karst of Northwestern Illinois and its Effects on Groundwater Quality. In Proceedings of the 14th Multidisciplinary Conference on Sinkholes and the Engineering and Environmental Impacts of Karst, Rochester, MN, USA, 5-9 October 2015; pp. 63-74.

66. Panno, S.V.; Krapac, I.G.; Weibel, C.P.; Bade, J.D. Groundwater Contamination in Karst Terrain of Southwestern Illinois; Environmental Geology Series No. 151; Illinois State Geological Survey: Champaign, IL, USA, 1996; p. 43.

67. Patel, P.; Raju, N.J.; Reddy, B.C.S.R.; Suresh, U.; Gossel, W.; Wycisk, P. Geochemical processes and multivariate statistical analysis for the assessment of groundwater quality in the Swarnamukhi River basin, Andhra Pradesh, India. Environ. Earth Sci. 2016, 75, 611. [CrossRef]

68. Goff, J.P. Macromineral physiology and application to the feeding of the dairy cow for prevention of milk fever and other periparturient mineral disorders. Anim. Feed Sci. Technol. 2006, 126, 237-257. [CrossRef]

69. Personne, J.C.; Poty, F.; Vaute, L.; Drogue, C. Survival, transport and dissemination of Escherichia coli and enterococci in a fissured environment. Study of a flood in a karstic aquifer. J. Appl. Microbiol. 1998, 84, 431-438. [CrossRef] [PubMed]

70. Panno, S.V.; Kelly, W.R.; Martinsek, A.T.; Hackley, K.C. Estimating background and threshold nitrate concentrations using probability graphs. Ground Water 2006, 44, 697-709. [CrossRef]

71. Peterson, E.W.; Hayden, K.M. Transport and Fate of Nitrate in the Streambed of a Low-Gradient Stream. Hydrology 2018, 5, 55. [CrossRef]

72. Duff, J.H.; Triska, F.J. Denitrification in sediments from the hyporheic zone adjacent to a small forested stream. Can. J. Fish. Aquat. Sci. 1990, 47, 1140-1147. [CrossRef]

73. Follett, R.F.; Delgado, J.A. Nitrogen fate and transport in agricultural systems. J. Soil Water Conserv. 2002, 57, 402-408. 
74. Hinkle, S.R.; Duff, J.H.; Triska, F.J.; Laenen, A.; Gates, E.B.; Bencala, K.E.; Wentz, D.A.; Silva, S.R. Linking hyporheic flow and nitrogen cycling near the Willamette River-A large river in Oregon, USA. J. Hydrol. 2001, 244, 157-180. [CrossRef] 